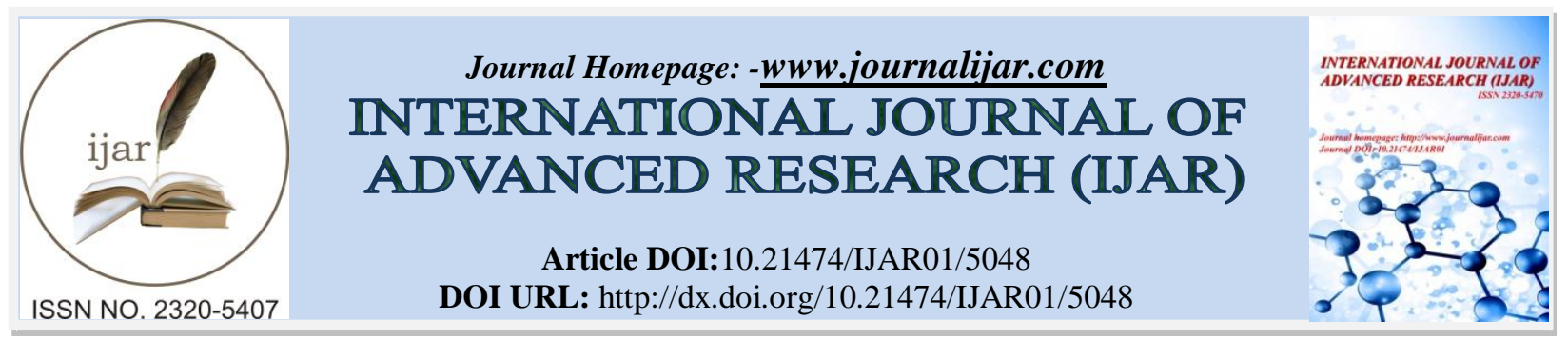

RESEARCH ARTICLE

\title{
INFORMATION NEEDS FOR CLIMATE CHANGE ADAPTATION AND CLIMATE SMART AGRICULTURAL TECHNOLOGIES AMONG RICE-PULSE GROWING FARMERS IN PURI DISTRICT OF ODISHA, INDIA.
}

Anmol Panda ${ }^{1}$ and Shivamurthy $\mathbf{M}^{\mathbf{2}}$.

1. M. Sc. Graduate, Department of Agricultural Extension, GKVK, UAS, Bangalore.

2. Professor\& Head,Department of Agricultural Extension, GKVK, UAS, Bangalore.

Manuscript Info
Manuscript History
Received: 03 June 2017
Final Accepted: 05 July 2017
Published: August 2017
Key words:-
Information needs; Climate change;
Adaptation; Climate Smart Agriculture
Technologies; Rice-pulse farmers

\begin{abstract}
Communication of timely and relevant information on climate change risks through credible sources is essential for mobilizing farmers to take actions to adapt for climate change. An informed farming society is better able to prepare for likely occurrence of climate disaster. The results of the study revealed that radio, extension workers, friends and relatives are the major sources of information on climate change and Climate Smart Agricultural Technologies. Farmers identified information needs on major areas of Climate change and Climate Smart Agricultural Technologies, among them effects of climate change, crops adaptable to climate change, Adaptation strategies, Flood/erosion control practices and Alternative/complementary livelihood activities are most important areas. The study recommended organizing capacity building programmes related to Climate Smart Agricultural technologies, timely generation and dissemination of information on climate change issues as strategies for enhancing adaptation to climate change.
\end{abstract}

Copy Right, IJAR, 2017,. All rights reserved.

\section{Introduction:-}

Climate change poses a major and growing threat to global food security. The effects of climate change are higher temperature, frequent extreme weather events, water shortages, rising sea levels, ocean acidification, land degradation, the disruption of ecosystems and the loss of biodiversity which could seriously compromise agriculture's ability to feed the most vulnerable, impeding progress towards the eradication of hunger, malnutrition and poverty. Climate change will have significant impacts on the livelihoods of rural poor in developing countries. Adaptation is an important component of climate change impact and vulnerability assessment, and is one of the policy options in response to climate change impacts (Fankhauser 1996, Smith and Lenhart 1996; Smit et al. 1999). Agriculture is inherently sensitive to climate conditions, and is among the most vulnerable sectors to the risks and impacts of global climate change (Reilly 1995). Studies show that without adaptation, climate change is generally problematic for agricultural production and for agricultural economies and communities; but with adaptation, vulnerability can be reduced and there are numerous opportunities to be realized (Fankhauser 1996; Smith 1996; Mendelsohn 1998; Wheaton and McIver 1999). Adaptation in the context of climate change comprises the measures taken to minimize the adverse impacts of climate change.

Corresponding Author:-Anmol Panda.

Address:-M. Sc. Graduate, Department of Agricultural Extension, GKVK, UAS, Bangalore. 
According to the World Meteorological Organization (2011) climate information and prediction services enable better management of climate variability and adaptation through the incorporation of science-based practices into planning, policy and practices on the global and national scale. Information is crucial in agricultural development which enables farmers to take decisions regarding their choice of practices in order to avert or reduce risks related to climate change and promote sustainable development.

India has been vulnerable to vagaries such as droughts, floods, heat waves and cyclones since time immemorial (High Powered Committee 2002). These vagaries have left behind death and destruction with huge impact on the developing economy of the country. India receives an annual average rainfall of around $1190 \mathrm{~mm}$ more than $75 \%$ of which is received in a span of four months from June to September. The performance of the Indian agrarian economy is very much dependant on these four months (Department of Agriculture and Cooperation 2004). The pattern of onset and withdrawal of the monsoon leaves the northwest India with little rainy period while the southwest and northeast parts of the country receive higher rainfall and longer rainy season. Coupled to this, the short and intense rainfall spells make the dry land areas more vulnerable to runoff losses and further drought proneness. The $68 \%$ of India's cropped area receives rainfall between $750-2,000 \mathrm{~mm}$ per annum. These areas are highly prone to irregularities in monsoons such as late onset, long breaks and early withdrawal etc and hence are vulnerable to droughts of different durations and magnitudes (Shaw et al. 2005).

Puri district of Odisha is a major producer of Rice and Pulses covering an area of 1.42 lakhs hectares of Rice and 70800 hectares of pulses production (Anon, 2017). Farmers in the district are frequently affected by erratic rainfall, water logging problems, salinity problems, wrong agronomic practices, flash floods and cyclonic storms during October-November which has led to decrease in yields of field crops ultimately affecting profit of farmer.

The concept of Climate Smart Agriculture (CSA) was first launched by FAO in 2010 in a background paper prepared for the Hague Conference on Agriculture, Food Security and Climate Change in the context of national food security and development goals, to tackle three main objectives:

- Sustainably increase food security by increasing agricultural productivity and incomes

- Build resilience and adapt to climate change

- Reduce and/or remove greenhouse gas emissions where possible.

Climate-Smart Agricultural Technologies seek to maximize synergies and minimize trade-offs in addressing food security, development and climate change adaptation/mitigation challenges.

According to USAID (2007) appropriate interventions must incorporate disaster planning response and mitigation into governance systems and engage vulnerable groups into participation to address their vulnerability and to identify adaptations to climate change impacts. Sustainable adaptation should also allow for decision making from all stakeholders, including poor men \& women and should incorporate site-specific information. Furthermore, involvement of local community members enhances ownership and sustainability maintains that transmitting climate information to the grassroots level is one of the major challenges to make climate and weather information relevant to vulnerable communities. (Lugon 2010 and Holmes 1996).

\section{Objectives of the study:-}

The study seeks to:

1. Determine the socio-economic characteristics of Rice-pulse farmers.

2. Identify farmers' sources of information about climate change and Climate Smart Agricultural Technologies.

3. Identify the farmers' information needs for climate change and Climate Smart Agricultural Technologies

4. Analyse the socio-economic determinants of the farmers' information needs for climate change adaptation and Climate Smart agricultural Technologies.

Against this background the following research questions were framed:

1. What are the farmers' sources of Climate change information and Climate Smart Agricultural Technologies?

2. What are the farmers' perceived information needs for climate change adaptations and Climate Smart Agricultural Technologies? 


\section{Methodology:-}

The Study was conducted in Puri district of Odisha state in India, purposively as most of the Rice-pulse farmers are under irrigated condition; further area under rice and pulses was considerably high in the district. Three taluks Pipili, Nimapara and Gop were selected taking maximum area under rice and pulses as criteria. From each of the selected taluks three villages were selected by applying simple random sampling technique. From each of these selected villages ten rice-pulse growers were randomly selected as respondents for the study and thus 90 farmers constituted the sample for study.

Data were obtained from primary sources with the aid of structured questionnaire and interview schedule from farmers in the study area.

Descriptive and inferential statistics tools were used to analyze data. Objective 1 was analyzed using frequency and mean statistics. Objective 2 was analyzed using bar chart. Objective 3 was analyzed using mean statistics. The hypothesis was analyzed using the ordinary Least Square Multiple regression implicitly represented by the equation:

$\mathrm{Y}=\mathrm{f}\left(\mathrm{X}_{1}+\mathrm{X}_{2}+\mathrm{X}_{3}+\mathrm{X}_{4}+\mathrm{X}_{5}+\mathrm{X}_{6}+\mathrm{X}_{7}+\mathrm{X}_{8}+\mathrm{X}_{9}+\mathrm{X}_{10}+\mathrm{X}_{11}+\mathrm{X}_{12}+\mathrm{X}_{13}+\mathrm{X}_{14}+\mathrm{X}_{15}\right)+\mathrm{e}$

Where $Y=$ Sum total of areas of information indicated by the farmers.

$\mathrm{X}_{1}=$ Age

$\mathrm{X}_{2}=$ Education

$\mathrm{X}_{3}=$ Family size

$\mathrm{X}_{4}=$ Family type

$\mathrm{X}_{5}=$ Size of Land Holding

$\mathrm{X}_{6}=$ Innovative Proneness

$\mathrm{X}_{7}=$ Material Possession

$\mathrm{X}_{8}=$ Farming experience

$\mathrm{X}_{9}=$ Extension Participation

$\mathrm{X}_{10}=$ Achievement Motivation

$\mathrm{X}_{11}=$ Risk Orientation

$\mathrm{X}_{12}=$ Scientific Orientation

$\mathrm{X}_{13}=$ Cosmopoliteness

$\mathrm{X}_{14}=$ Animal herd size.

$\mathrm{X}_{15}=$ Ownership and extent of utilization of ICTs

The four functional forms of the model were tested and the one with the best fit; highest number of F-value, coefficient of multiple determinations (R2) and highest number of significant variables was chosen for the analysis.

\section{Results and Discussion:-}

\section{Socio-economic characteristics of the rice-pulse growing farmers:-}

Age: Data in Table 1 shows that slightly more than half $(53.33 \%)$ of the respondents belonged to middle age category (31-50 years) followed by 44.44 per cent under old age (Above 50 years) and 2.22 per cent of farmers belonged to young age (Less than 31 years) group respectively. Mean age of the farmer was 50 years. Farmers of middle age are enthusiastic and more efficient than the younger and older ones. Further individuals with 31 to 50 years of age group have physical vigour and more responsibility towards family than the younger ones. The results were in line with the research findings of independent variable age reported by Hiremath (2007) and Jamadar (2012).

Education: Data in Table 1 shows that 48.89 per cent of the respondents were having medium education followed by high (38.89\%) and low (12.22\%) education. Realizing importance of formal education in ones development by the parents of respondents might have motivated them to send their children for schooling. However, the distance of higher education centers from the village might have prevented them from getting higher education. The findings got supports from the studies on education as an independent variable conducted by Palaniswamy et al. (2001) and Mahatab (2010).

Family size: Data in Table 1 shows that about 64.44 per cent of the rice-pulse growers belongs to medium family size with 4-6 members followed by 31.11 per cent of farmers had large family size with 7 and more members and 
only 4.44 per cent farmers belongs small family size up to three members respectively. It is a common feature in the rural areas of the district to be in large family, since rice-pulse growing is labour intensive and being in a large family it would meet the labour requirements. The findings were in line with the result of study of Shukla $e t$ al. (2009) taken family size as an independent variable.

Family type: Data in Table 1 show that majority $(66.66 \%)$ of the respondents belonged to nuclear family and rest of the respondents belonged to joint family. The growing urbanization might have influence the people to prefer nuclear families which could satisfy the basic needs of the family for better harmony. The findings were in line with results of Sophiasatyavathy (2001), Rangi et al. (2002) and contradict with Dutta (2015).

Size of land holding: Data in Table 1 show that about 76.67 percent of respondents were marginal farmers followed by small $(14.44 \%)$ and large farmers $(8.89 \%)$ respectively. Fragmentation of the ancestral land holding from generation to generation might have lead to smaller size land holdings, the other probable reason may be that those who had occupations other than agriculture might have less acres of land. The findings of the study were in line with the findings of Adewale et al. (2007).

Innovative proneness: Data in Table 1 show that about 45.56 per cent of respondents belong to medium innovative proneness category followed by 30 percent in low innovative proneness and 24.44 per cent in high innovative proneness categories respectively. As majority of farmers had medium level of education, there is medium level of innovativeness among the farmers. The results were in conformity with the findings of Kalyan (2011) and Jamadar (2012).

Material possession: Data in Table 1 show that 41.11 per cent of farmers had medium level of material possession followed by 35.56 per cent of farmers had low level and 23.33 per cent of farmers had high material possession respectively. This might be the fact that possessing important farm implements and other equipments like bullock cart, sprayer, radio and television will encourage the farmers to adopt scientific cultivation practices. The findings are in consistent with the result reported by Kittur (1976).

Table 1:-Socio-economic profile of Rice-pulse farmers

\begin{tabular}{|c|c|c|c|c|c|}
\hline Sl. No. & $\begin{array}{l}\text { Socio-economic } \\
\text { characteristics }\end{array}$ & Category & Frequency & percentage & Mean Score- \\
\hline \multirow[t]{3}{*}{1} & \multirow[t]{3}{*}{ Age } & Old & 40 & 44.44 & \multirow{3}{*}{50.27} \\
\hline & & Middle & 48 & 53.33 & \\
\hline & & Young & 02 & 2.22 & \\
\hline \multirow[t]{3}{*}{2} & \multirow[t]{3}{*}{ Education } & Low & 11 & 12.22 & \multirow{3}{*}{2.38} \\
\hline & & Medium & 44 & 48.89 & \\
\hline & & High & 35 & 38.89 & \\
\hline \multirow[t]{3}{*}{3} & \multirow[t]{3}{*}{ Family size } & Small & 4 & 4.44 & \multirow{3}{*}{2.27} \\
\hline & & Medium & 58 & 64.44 & \\
\hline & & Large & 28 & 31.11 & \\
\hline \multirow[t]{2}{*}{4} & \multirow[t]{2}{*}{ Family type } & Nuclear & 60 & 66.67 & \multirow[t]{2}{*}{1.33} \\
\hline & & Joint & 30 & 33.33 & \\
\hline \multirow[t]{3}{*}{5} & \multirow[t]{3}{*}{ Size of land holding } & Marginal & 69 & 76.67 & \multirow[t]{3}{*}{1.31} \\
\hline & & Small & 13 & 14.44 & \\
\hline & & Large & 8 & 8.89 & \\
\hline \multirow[t]{3}{*}{6} & \multirow[t]{3}{*}{ Innovative proneness } & Low & 27 & 30 & \multirow{3}{*}{39.64} \\
\hline & & Medium & 41 & 45.56 & \\
\hline & & High & 22 & 24.44 & \\
\hline \multirow[t]{3}{*}{7} & \multirow[t]{3}{*}{ Material possession } & Low & 32 & 35.56 & \multirow{3}{*}{16.37} \\
\hline & & Medium & 37 & 41.11 & \\
\hline & & High & 21 & 23.33 & \\
\hline \multirow[t]{3}{*}{8} & \multirow[t]{3}{*}{ Risk orientation } & Low & 25 & 27.78 & \multirow{3}{*}{22.27} \\
\hline & & Medium & 33 & 36.67 & \\
\hline & & High & 32 & 35.56 & \\
\hline 9 & Scientific orientation & Low & 25 & 27.78 & \\
\hline
\end{tabular}




\begin{tabular}{|c|c|c|c|c|c|}
\hline & & Medium & 38 & 42.22 & \multirow{2}{*}{17.08} \\
\hline & & High & 27 & 30 & \\
\hline \multirow[t]{3}{*}{10} & \multirow[t]{3}{*}{ Farming experience } & Low & 43 & 47.78 & \multirow{3}{*}{3.45} \\
\hline & & Medium & 0 & 0 & \\
\hline & & High & 47 & 52.28 & \\
\hline \multirow[t]{3}{*}{11} & \multirow[t]{3}{*}{ Extension participation } & Low & 28 & 31.11 & \multirow{3}{*}{3.83} \\
\hline & & Medium & 32 & 35.56 & \\
\hline & & High & 30 & 33.33 & \\
\hline \multirow[t]{3}{*}{12} & \multirow[t]{3}{*}{ Achievement motivation } & Low & 28 & 31.11 & \multirow{3}{*}{25.84} \\
\hline & & Medium & 35 & 38.89 & \\
\hline & & High & 27 & 30 & \\
\hline \multirow[t]{3}{*}{13} & \multirow[t]{3}{*}{ Cosmopoliteness } & Low & 40 & 44.44 & \multirow{3}{*}{7.07} \\
\hline & & Medium & 28 & 31.11 & \\
\hline & & High & 22 & 24.44 & \\
\hline \multirow[t]{3}{*}{14} & \multirow[t]{3}{*}{ Animal herd size } & Low & 35 & 38.89 & \multirow{3}{*}{2.65} \\
\hline & & Medium & 30 & 33.33 & \\
\hline & & High & 25 & 27.78 & \\
\hline \multirow[t]{3}{*}{15} & \multirow{3}{*}{$\begin{array}{l}\text { Ownership and extent of } \\
\text { Utilization of ICTs. }\end{array}$} & Low & 27 & 30 & \multirow{3}{*}{7.27} \\
\hline & & Medium & 36 & 40 & \\
\hline & & High & 27 & 30 & \\
\hline
\end{tabular}

Risk orientation: Table 1 shows about 36.67 per cent of rice pulse growers belong to medium level risk orientation followed by 35.56 per cent of high risk orientation and 27.78 per cent in low level of risk orientation respectively. The reason for this may be they did not get the required encouragement and support to take up new activities. Those who possess high education, higher farm experience and high achievement motivation had increase risk orientation. The findings of the study were in line with the findings of Arathy (2011) and Rane (2016) and contradict with Jamadar (2012).

Scientific orientation: Table 1 show that 42.22 per cent of respondents belong to medium level of scientific orientation, followed by 30 per cent in high scientific orientation and 27.78 per cent in low scientific orientation respectively. Reasons might be medium level education of the farmers which further affects his/her adoption behaviour. The findings of the study were in line with Patel (2008) and Dutta (2015).

Farming experience: Table 1 show that slightly more than half $(52.22 \%)$ of the respondents are having high farming experience with respect to rice-pulse cultivation while, 47.78 per cent of respondents have low farming experience. None of them had medium farming experience. As by growing rice-pulse crop farmers might be getting more income compared to any other crop. Also, availability of sufficient moisture due to better irrigation might have resulted in higher farming experience. The findings of the study were in line with Satish (2010) and contradict with Rane (2016).

Extension participation: Table 1 show that 35.56 per cent of the rice-pulse growers belong to medium extension participation, followed by 33.33 per cent of farmers have high level and 31.11 per cent of the farmers had low level of extension participation respectively. The reason for this may be that extension activities like demonstration, training programme, and exhibition were not arranged in their village or nearby village. Lack of accessibility to go to these far off places prevented them in participating in the above activities. Hence many of them could not participate in some activities like field day, group meetings and demonstrations wherever it was possible. The findings of the study were in line with the findings of Dutta (2015) and contradicts with the study Tiwari et al. (2007).

Achievement motivation: Table 1 show that 38.89 per cent of the rice-pulse growers belong to medium level achievement motivation, followed by 31.11 per cent of farmers have high level and 30 per cent had low level of achievement motivation respectively. This is because many of them had low exposure to outside world. It also depends on the level of encouragement given by the family members and financial background. Though some of them had high motivation to achieve something they will not be in a position to express it because of many restrictions. Also they have to concentrate on the family and take care of house hold activities than to achieve new 
things. But still some have high achievement motivation, enthusiastic and optimistic to carry out new activities. The findings of the study were in line with the finding of Suresh (2004).

Cosmopoliteness: Table 1 show that 44.44 per cent of rice-pulse growers have low level of cosmopoliteness followed by medium level $(31.11 \%)$ and 24.44 per cent of high level of cosmopoliteness respectively. The reasons may be that, paddy as an intensive crop did not allowed them free time to attend for other activities. Further who have medium to high level of cosmopoliteness might have made them cosmopolite to facilitate selling of the produce in the nearby taluk or district headquarters. The findings of the study were in line with the findings of Verma (2009) and contradict with the findings of Dutta (2015).

Animal herd size: Table 1 show that 38.89 per cent of rice-pulse growers have low level of animal herd size, followed by 33.33 per cent of medium level and 27.78 per cent have high level of animal herd size respectively. The factor which might have been responsible for the variation in animal herd size is the difficulties to maintain animals. The findings of the study were in line with the findings of Arora et al. (2006) and contradict with Verma (2009).

Ownership and extent of utilization of ICTs: Table 1 show that 40 per cent of farmers have medium level of ownership and utilization of ICTs, followed by 30 per cent of both high and low level of ownership and ICT utilization respectively. Due to medium level of education among farmers they might unable to use new ICT gadgets and as large number of farmers at the study area are marginal farmers and unable to buy many ICT tools. The findings of the study were in line with Yadav et al. (2006).

Sources of information on climate change and Climate Smart Agricultural Technologies: Data in Table 2 reveals that majority of farmers received information on climate change and Climate Smart Agricultural Technologies through radio while the remaining received information through extension agents, friends, relatives and Assistant Agricultural officers.

Table 2:-Sources of information on climate change and Climate Smart Agricultural Technologies by the farmers

\begin{tabular}{|c|c|c|c|c|c|c|c|c|}
\hline \multirow{2}{*}{$\begin{array}{l}\text { Sl } \\
\text { No. }\end{array}$} & \multirow[t]{2}{*}{ Sources } & \multicolumn{2}{|c|}{ Always } & \multicolumn{2}{|c|}{ Some times } & \multicolumn{2}{|c|}{ Never } & \multirow{2}{*}{$\begin{array}{l}\text { Mean } \\
\text { score }\end{array}$} \\
\hline & & no & $\%$ & No & $\%$ & No & $\%$ & \\
\hline 1 & Radio & 36 & 40 & 45 & 50 & 9 & 10 & 2.30 \\
\hline 2 & $\begin{array}{l}\text { Agriculture department } \\
\text { Extension workers: }\end{array}$ & 28 & 31.11 & 61 & 67.78 & 1 & 1.11 & 2.29 \\
\hline 3 & Friends & 35 & 38.89 & 28 & 31.11 & 27 & 30.00 & 2.09 \\
\hline 4 & Relatives & 28 & 31.11 & 39 & 43.33 & 23 & 25.56 & 2.06 \\
\hline 5 & $\mathrm{AAO}$ & 7 & 7.78 & 53 & 58.89 & 30 & 33.33 & 1.74 \\
\hline 6 & TV & 12 & 13.33 & 39 & 43.33 & 39 & 43.33 & 1.68 \\
\hline 7 & Asst. horticultural officer & 5 & 5.56 & 38 & 42.22 & 47 & 52.22 & 1.53 \\
\hline 8 & $\mathrm{AO}$ & 2 & 2.22 & 35 & 38.89 & 53 & 58.89 & 1.41 \\
\hline 9 & News paper & 5 & 5.55 & 25 & 27.78 & 60 & 66.67 & 1.40 \\
\hline 10 & $\mathrm{NGO}$ & 4 & 4.44 & 27 & 30 & 59 & 65.56 & 1.39 \\
\hline 11 & Magazines & 4 & 4.44 & 15 & 16.67 & 71 & 78.89 & 1.26 \\
\hline 12 & Private extension worker & 3 & 3.33 & 12 & 13.33 & 75 & 83.33 & 1.20 \\
\hline 13 & University scientists & 1 & 1.11 & 7 & 7.78 & 82 & 91.11 & 1.11 \\
\hline
\end{tabular}




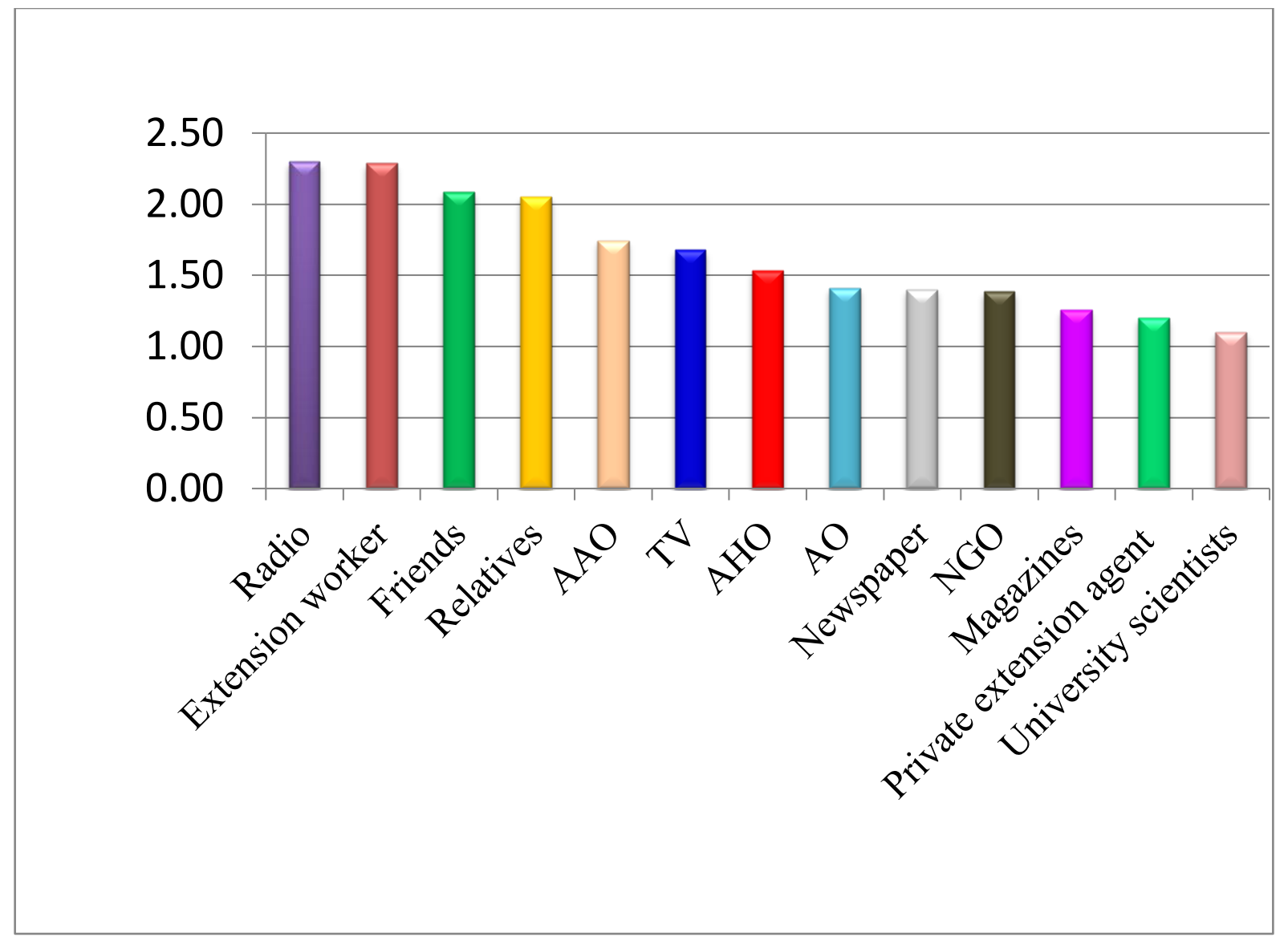

Fig 1:-Sources of information on climate change and Climate Smart Agricultural Technologies.

Areas of information needs for climate change adaptation and Climate Smart Agricultural Technologies:Data in Table 3 indicates that farmers expressed that they needed information on effects of climate change $(M=2.49)$, crops adaptable to climate change $(M=2.42)$, Adaptation strategies $(M=2.40)$, flood/erosion control practices $(\mathrm{M}=2.36)$, alternative/complementary livelihood activities $(\mathrm{M}=2.24)$, vulnerable groups to climate change $(\mathrm{M}=2.18)$, causes of climate change $(\mathrm{M}=1.99)$, appropriate socio-cultural practices in climate change $(\mathrm{M}=1.89)$, sources of information on climate change $(\mathrm{M}=1.80)$, Agroforestry practices $(\mathrm{M}=1.49)$ and carbon trading $(\mathrm{M}=1.23)$.

Table 3:-Distribution of Rice-pulse farmers according to information needs for climate change adaptation and Climate Smart Agricultural Technologies

\begin{tabular}{|c|c|c|c|c|c|c|c|c|c|}
\hline \multirow[t]{2}{*}{$\begin{array}{l}\text { Sl } \\
\text { no. }\end{array}$} & \multirow[t]{2}{*}{ Areas of information need } & \multicolumn{2}{|c|}{$\begin{array}{l}\text { Most } \\
\text { important }\end{array}$} & \multicolumn{2}{|c|}{ Important } & \multicolumn{2}{|c|}{\begin{tabular}{|l|} 
Less \\
important
\end{tabular}} & \multirow[t]{2}{*}{ Rank } & \multirow[t]{2}{*}{$\begin{array}{l}\text { Mean } \\
\text { score }\end{array}$} \\
\hline & & No. & $\%$ & No. & $\%$ & No & $\%$ & & \\
\hline 1 & Effects of climate change & 49 & 54.44 & 36 & 40 & 5 & 5.56 & 1 & 2.49 \\
\hline 2 & Crops adaptable to climate change & 41 & 45.56 & 46 & 51.11 & 3 & 3.33 & 2 & 2.42 \\
\hline 3 & Adaptation strategies & 44 & 48.89 & 38 & 42.22 & 8 & 8.89 & 3 & 2.40 \\
\hline 4 & Flood/erosion control practices & 42 & 46.67 & 38 & 42.22 & 10 & 11.11 & 4 & 2.36 \\
\hline 5 & $\begin{array}{l}\text { Alternative/complementary } \\
\text { livelihood activities }\end{array}$ & 32 & 35.56 & 48 & 53.33 & 10 & 11.11 & 5 & 2.24 \\
\hline 6 & $\begin{array}{l}\begin{array}{l}\text { Vulnerable groups to climate } \\
\text { change }\end{array} \\
\end{array}$ & 29 & 32.22 & 48 & 53.33 & 13 & 14.44 & 6 & 2.18 \\
\hline 7 & Causes of climate change & 14 & 15.56 & 61 & 67.78 & 15 & 16.67 & 7 & 1.99 \\
\hline 8 & Appropriate socio-cultural practices & 15 & 16.67 & 50 & 55.56 & 25 & 27.78 & 8 & 1.89 \\
\hline
\end{tabular}




\begin{tabular}{|l|l|l|l|l|l|l|l|l|l|}
\hline & in climate change & & & & & & & & \\
\hline 9 & $\begin{array}{l}\text { Sources of information on climate } \\
\text { change }\end{array}$ & 11 & 12.22 & 50 & 55.56 & 29 & 32.22 & 9 & 1.80 \\
\hline 10 & Agroforestry practices & 4 & 4.44 & 36 & 40 & 50 & 55.56 & 10 & 1.49 \\
\hline 11 & Carbon trading & 2 & 2.22 & 17 & 18.89 & 71 & 78.89 & 11 & 1.23 \\
\hline
\end{tabular}

Socio-economic determinants of farmers information needs for climate change adaptation and Climate Smart Agricultural Technologies.

The result in Table 4 shows that Exponential function had highest coefficient of multiple determination $\mathrm{R}^{2}(0.33)$ and F-value (2.46). Thus, it serves as the lead equation for the explanation of the relationship.

The result shows that there was a less significant relationship between socio-economic characteristics of the farmers and areas of information needs on climate change adaptation. The result implies that the combined effects of all the variables accounted for $33 \%$ variation on the information needs of the farmers for climate change adaptation and Climate Smart Agricultural Technologies. The significant variables were scientific orientation and achievement motivation.

Variable scientific orientation was negatively significant to the farmers' information needs for climate change adaptation and Climate Smart agricultural Technologies. It implies that scientific orientation of farmer reduced the farmers' need for information. This might be the reason due to less land holding, medium material possession and medium education people hesitate to adopt technologies and acquire information related to climate change adaptation even after having necessary scientific orientation. The findings of study are in confirmatory with Jamadar (2012)

Variable achievement motivation was positively significant with respect to the farmers' information needs for climate change adaptation and Climate Smart Agricultural Technologies. The possible reasons may be that farmers having higher achievement motivation will have tendency to gather information about new innovations and technologies which will help them to accomplish their goals. The findings of the study are in confirmatory with Rao (1995) and Chandregowda (1997).

However, other variables were not significantly related to the information needs of the farmers for climate change adaptation and Climate Smart Agricultural Technologies. They are inconsequential and as such do not exert any significant effects.

Table 4:-Regression analysis of farmers' socio-economic characteristics and their information needs for climate change adaptation and Climate Smart Agricultural Technologies.

\begin{tabular}{|c|c|c|c|c|}
\hline & & & & $(n=90)$ \\
\hline Explanatory variables & $\begin{array}{l}\text { Linear } \\
\text { function }\end{array}$ & $\begin{array}{l}\text { Semi-log function } \\
(\log x)\end{array}$ & \begin{tabular}{|l|}
$\begin{array}{l}\text { Semi-log function } \\
(\log y)\end{array}$ \\
\end{tabular} & $\begin{array}{l}\text { Exponential } \log \\
\text { function }\end{array}$ \\
\hline $\mathrm{R}^{2}$ & 0.29 & 0.32 & 0.29 & 0.33 \\
\hline No of observation & 90 & 90 & 90 & 90 \\
\hline Degrees of freedom & 89 & 89 & 89 & 89 \\
\hline F-value & 2.04 & 2.37 & 2.07 & 2.46 \\
\hline X1(Age) & -0.67 & -4.18 & -0.01 & -0.09 \\
\hline X2 (Education) & -0.13 & -0.86 & 0.00 & -0.02 \\
\hline X3 (Family size) & 0.43 & 2.15 & 0.01 & 0.05 \\
\hline X4 (Family type) & 0.12 & 0.69 & 0.00 & 0.01 \\
\hline X5 (Size of land holding) & -0.64 & -3.21 & -0.01 & -0.06 \\
\hline X6(innovative proneness) & 0.03 & 3.71 & 0.00 & 0.06 \\
\hline X7 (Material possession) & 0.02 & 3.84 & 0.00 & 0.08 \\
\hline X8 (Farming experience) & 0.19 & 7.85 & 0.00 & 0.15 \\
\hline $\begin{array}{l}\mathrm{X} 9 \text { (Extension } \\
\text { participation) }\end{array}$ & -0.35 & -15.51 & -0.01 & -0.31 \\
\hline X10(Achievement motivation) & $0.23^{* *}$ & $2.90 * *$ & $0.00 * *$ & $0.05^{* *}$ \\
\hline X11 (Risk orientation) & -0.20 & -2.28 & 0.00 & -0.04 \\
\hline
\end{tabular}




\begin{tabular}{|l|l|l|l|l|}
\hline X12(Scientific orientation) & $0.46^{* *}$ & $25.79 * *$ & $0.01^{* *}$ & $0.52^{* *}$ \\
\hline X13 (Cosmopoliteness) & 0.00 & -0.49 & 0.00 & 0.00 \\
\hline X14 (Animal herd size) & -0.05 & -1.09 & 0.00 & -0.02 \\
\hline $\begin{array}{l}\text { X15 (Ownership and extent of } \\
\text { utilization of ICTs) }\end{array}$ & -0.18 & -3.35 & 0.00 & -0.08 \\
\hline
\end{tabular}

\section{Conclusion:-}

Adaptation to climate change has remained a viable option for dealing with the impacts and effects of climate change. However, this will remain ineffective and unsustainable without the timely generation and dissemination of useful information on climate change to the people whose livelihoods are mostly affected. This as it has been pointed out will enhance the necessary decision making aimed at reducing the impacts.

The findings of the study indicated that farmers in Puri district of Odisha needed information on mitigation issues for easy adaptation to climate change and information regarding Climate Smart Agricultural Technologies. These are determined by the socio-economic characteristics, achievement motivation and scientific orientation.

Capacity building programmes relevant to climate change and information related to Climate Smart Agricultural technologies should be organized by developmental agencies at all levels to farmers as well as extension agents to enhance their capacities for effective and sustainable adaptation to climate change.

Nearby institutions like National Rice Research Institute and Odisha University of Agriculture and Technology should ensure timely generation and dissemination of relevant information on climate change which should cover all the areas of needs indicated by farmers to enable them to make decisions which will enhance their adaptation to climate change.

\section{References:-}

1. ADEWALE, J. G., OLANIYI, O. A. AND ADAMOU, N. A., 2007, Farmers adoption of improved rice technology in Niamy. World J. Agric. Sci., 3 (4): 530-535

2. ANONYMOUS, 2017, Odisha economic survey 2016-17.Planning and Convergence department, Directorate of Economics and statistics, Government of Odisha.

3. ARATHY, B., 2011, Constraint analysis of rice farmers of Thrissur district of Kerala. M.Sc. (Agri.) Thesis (Unpub.), ANGRAU, Hyderabad

4. ARORA, A. S., KUMAR, A., BARDHAN, D. AND DABAS, Y. P. S., 2006, Socioeconomic and communicational variables associated with level of knowledge and degree of adoption of improved dairy husbandry practices in U.S. Nagar district of Uttaranchal. Ind. J. Dairy Sci., 59 (5): 337-343

5. CHANDRE GOWDA, K. N., 1997, A study on extent of adoption of improved cultivation practices of chrysanthemum. M.Sc. (Agri.) Thesis, (Unpub.), Univ. Agric. Sci., Bangalore

6. DEPARTMENT OF AGRICULTURE AND COOPERATION, 2004, Drought 2002: A Report, Department of Agriculture and Cooperation, Ministry of Agriculture, New Delhi, P. 190

7. DUTTA BIBHU PRASAD, 2015, A study on the Adoption behaviour of rice farmers towards Alternate Wetting And Drying (AWD) technology in Puri district of Odisha. M.Sc. (Agri.) Thesis (Unpub.), OUAT, Bhubaneswar.

8. FANKHAUSER, S., 1996, 'The potential costs of climate change adaptation, Adapting to Climate Change: An International Perspective, New York, Springer, pp. 80-96.

9. HIGH POWERED COMMITTEE (2002) Disaster management report, Department of Agriculture and Cooperation, Ministry of Agriculture, Government of India, India, p 107

10. HIREMATH, V., 2007, Knowledge and adoption behaviour of vegetable growers with respect to Eco-friendly technologies. M.Sc. (Agri.) Thesis (Unpub.), Univ. Agric. Sci., Bangalore

11. JAMADAR, 2012, Farmer awareness of climate change and their adaptations. M.Sc. Thesis (Unpub.), Univ. Of Agril. Sci., Dharwad.

12. KALYAN, V. N., 2011, Impact analysis of groundnut production technologies in Chittoor district of Andhra Pradesh. M.Sc. (Agri.) Thesis (Unpub.), Univ. Agric. Sci., Dharwad

13. KITTUR, M. M., 1976, A study on adoption behaviour of marginal farmers in relation to their characteristics and value orientation in Bijapur district. M.Sc. (Agri.) Thesis (Unpub.), Univ. Agric. Sci., Bangalore. 
14. MAHATAB ALI, K. M., 2010, A study on knowledge and adoption of aerobic rice growers in eastern dry zone of Karnataka state M. Sc. (Agri.) Thesis (Unpub.), Univ. Agric. Sci., Bangalore, Karnataka.

15. MENDELSOHN, R.: 1998, 'Climate-change damages', in W.D. Nordaus, (ed.), Economics and Policy Issues in Climate Change, Washington, D.C., Resources for the Future

16. PALANISWAMY, K. AND SRIRAM, M. S., 2001, A scale to measure extension participation of farmers. Indian J. Ext. Educ., 19: 325-328.

17. PATEL, M. K., 2008, A Study on technological gap in recommended soybean production technology among the farmers of Kabirdham district of Chattisgarh state. M.Sc. (Agri.) Thesis (Unpub.), IGKV, Raipur.

18. RANE SATISH, 2016, A study on adoption of Eco-friendly technologies among rice growers of Hanumana block of Rewa district (M.P.), M.Sc. (Agri.)Thesis (Unpub.), JNKVV

19. RANGI P. S., SIDHU M. S. AND HARJIT SINGH, 2002, Economic empowerment of rural women through self helps groups: A case study of Fatehgarh Sahib district (Punjab).Man and development, 24 (3): 65-78.

20. REILLY, J.: 1995, 'Climate change and global agriculture: Recent findings and issues', Amer. J. Agric. Econ. 77, 727-733.

21. SHAW R., PRABHAKAR S. V. R. K., FUJIEDA A., 2005, Community level climate change adaptation and policy issues: a case study from Gujarat, India. Graduate School of Global Environmental Studies. Kyoto University, Japan, p 59

22. SHUKLA, Y. K., SHUKLA, R., TOMAR, S. S. AND KUMAR, R., 2009, Adoption and constraint of vermin compost technology. Paper presented In: National Seminar on Organic farming. RVSKVV, Gwalior. p.113

23. SMIT, B., BURTON, I., KLEIN, R.J.T. AND STREET, R.: 1999, 'The science of adaptation: A framework for assessment', Miti. \& Adaptation Strat. for Glob. Change, 4, 199-213

24. SMITH, J.B.: 1996, 'Using a decision matrix to assess climate change adaptation', Adapting to Climate Change: An international Perspective, New York, Springer, pp. 68-79

25. SMITH, J.B. AND LENHART, S.S.: 1996, Climate change adaptation policy options, Clim. Res. 6, $193-201$.

26. SOPHIASATHYAVATHY, 2001, A study on knowledge and adoption of sustainable cultivation practices in sugarcane and cotton by farmers in Cuddalore district of Tamil Nadu. M.Sc. (Agri.) thesis (Unpub.) Univ. Agric. Sci., Dharwad.

27. SURESH, 2004, Entrepreneurial behaviour of milk producers in Chitoor district of Andhra Pradesh - a critical supply. M. V. Sc. Thesis (Unpub.), Acharya N. G. Agril. Univ., Hyderabad

28. TIWARI, S. G., GARG, S. K., YADAV, R. K. AND MORYA, J., 2012, Communications Gap in Chickpea production technology of the Chick pea growers. Indian research Journal of Extension Education, 2: 81-83

29. UNITED STATES AGENCY FOR INTERNATIONAL DEVELOPMENT, 2007, Adapting to climate variability and change, a guidance manual for development planning. USAID and stratus consulting, Washington.

30. VERMA SATISH KUMAR, 2009, A study on Knowledge and adoption of Organic farming practices in paddy cultivation among tribal farmers of Kanker district, M. Sc. Thesis (Unpub.), IGKV Chattisgarh

31. WHEATON, E.E. AND MCIVER, D.C.: 1999, 'A framework and key questions for adapting to climate variability and change', Miti. \& Adapt. Strat. for Glob. Change,4: 215-225

32. WORLD METEOROLOGICAL INSTITUTE, 2007, Climate information for adaptation and development needs. WMO 1025

33. YADAV, V. P. S., RAMAN, R. S. AND KUMAR, R. 2006, Knowledge and attitude of farmers towards soil testing practices. Indian J. Extn. Educ. 6 (3): 20-21. 